\title{
DEVELOPMENT OF ATTITUDE TOWARDS REFLECTIVE TEACHING PRACTICE (RTP) SCALE
}

\author{
Karuna K Simha \\ Dr. Umme Kulsum
}

\begin{abstract}
The NCF-2005, NCFTE-2009 and the New Education Policy-2020 recommend teachers to be reflective practitioners. The realization of the concept of reflective teaching practice helps us to openly accept the new changes that are brought about by the education system and enables us to progress towards the betterment of the education system. The fundamental principle of teacher education is to be on reflective teaching model. As the reflective practice has been introduced more recently, there has been a shift in the approaches of teaching from teacher centeredness to learner centeredness. Adapting to the novel changes requires a mind-set to acknowledge the changes and evolve according to the need. It also involves likes and dislikes which can be rightly called attitudes. It is helpful to know the level of attitude of teachers, so as to provide them with required training, motivation and support. This helps the teachers also to change their attitudes towards reflective teaching. The measurement of attitude towards reflective teaching practices enables the teacher-educators, the educationists and the government to design programmes to help teachers develop a positive attitude to the new recommendations. It also helps the teacher education institutions to inculcate the positive attitudes towards the reflective teaching so as to prepare the entrant teachers to become reflective practitioners. Hence the attitude scale was constructed. The main purpose of the attitude scale is to measure and quantify the attitude towards reflective teaching practices. The reflective teaching practice scale was developed based on Likert
\end{abstract}


Towards Excellence: An Indexed, Refereed \& Peer Reviewed Journal of Higher Education / Karuna K

Simha \& Dr. Umme Kulsum / Page 337-348

scale construction procedures. The theoretical framework was adopted from the Pollard's Reflective Teaching.

\section{Index terms- Attitude, reflective teaching practice, Likert scale development Introduction}

The NCF-2005, NCFTE-2009 and the New Education Policy-2020 recommend teachers to be reflective practitioners. The realization of the concept of reflective teaching practice helps us to openly accept the new changes that are brought about by the education system and enables us to progress towards the betterment of the education system. The fundamental principle of teacher education is to be on reflective teaching model. Both experienced and novice teachers can get benefit from it. The elements of reflective teaching is useful in bringing a one to one correspondence between lesson planning implementation of the plan and also evaluation processes.(Minnott,2006).

As the reflective practice has been introduced more recently, there has been a shift in the approaches of teaching from teacher centeredness to learner centeredness. Adapting to the novel changes requires a mind-set to acknowledge the changes and evolve according to the need. It also involves likes and dislikes which can be rightly called attitudes. Attitudes play an important role in the process of adaptation to the change. A positive attitude accelerates the process of adaptation and acceptance with more ease whereas the slightly less positive attitude delay the process. Hence attitudes towards reflective teaching practices, when developed positively, helps the teacher to adapt efficiently and perform better to the new recommendations.

\section{Need For Attitude Towards Reflective Practice Scale}

As a need of the hour, teachers are required to be reflective practitioners. This involves problem raising and problem solving in a classroom. Reflective practices are not just restricted to classroom teaching, but also involves several aspects of teaching profession. When a teacher has the right attitude towards reflective teaching practices, process of evolving as a reflective practitioner as 
recommended by the NCF-2005 becomes effortless. Whereas those with difficulty in adapting to the change have less positive attitude towards the changes. It is an obvious human behaviour to have less positive attitude towards the difficulties faced. This requires them to understand the concept of reflection, practice reflective procedures and gradually adapt to the new processes in education. The teaching practices need to shift from teacher centered approaches to student centered approaches. Therefore it is helpful to know the level of attitude of teachers, so as to provide them with required training, motivation and support. This helps the teachers also to change their attitudes towards reflective teaching. With the support and training the teachers tend to become reflective practitioners. Hence the measurement of attitude towards reflective teaching practices becomes a necessity. This measurement enables the teacher-educators, the educationists and the government to design programmes to help teachers develop a positive attitude to the new recommendations. It enables the government to provide for the training and motivation of the teachers based on their attitude. It also helps the teacher education institutions to inculcate the positive attitudes towards the reflective teaching so as to prepare the entrant teachers to become reflective practitioners.

\section{Preparation Of The Tool}

The main purpose of the attitude scale is to measure and quantify the attitude towards reflective teaching practices of B.Ed., students. The literature related to the reflective practices were reviewed by the investigator for deriving the components of the study. The dimensions were derived based on reflective teaching by pollard (Pollard,2005). The theory about reflective teaching as given by Pollard et al has been considered for the study and the items have been derived from the theoretical background. The scale was constructed based on the guidelines for the construction of Likert scales. Initially a total of 36 items were constructed across the five dimensions. The investigator could derive five broad components from the theoretical understanding, which are as follows 
1. Teaching strategies (TS)

2. Classroom Episodes (CLEP)

3. Interpersonal Relationship \& Communication (IRC)

4. Assessment Of Learning (AOL)

5. Self-Evaluation (SE)

\section{A. Dimensions}

The five dimensions considered are comprehensive to reflective classrooms. It covers most of the observable phenomenon in an on-going classroom. Teaching strategies (TS) here represents all the methodological strategies that a teacher uses in the course of facilitating learning. The classroom episodes (CLEP) are all the processes and strategies that are applied by the teacher to manage a class, use available resources effectively and manage learning. It also includes the overall working dynamics in a classroom. The interpersonal relationship and communication (IRC), as the name represents, includes the interactions between teacher and students, the quality of 'The Teacher Talk', and other communication channels that help a reflective classroom. In assessment of learning (AOL) the investigator considers formative assessments extensively as it can be observed in an on-going classroom. The reason is immediate reflections are more evidently received through formative assessment. For reflection-in-action the formative assessment techniques are best fitted and are a powerful feedback system for a teacher during a class. It not only gives reflections on student's direction of learning, but also provides reflections of teacher's performances. Self-evaluation (SE) is an important process in reflective practices. It helps a teacher to introspect his/her actions, feelings and strategies. It also helps the teacher to find the areas for improvement, work on the weaker parts and hence progress towards facilitating effective learning. With the above described dimensions, the items were written and edited as per expert suggestions. 
Towards Excellence: An Indexed, Refereed \& Peer Reviewed Journal of Higher Education / Karuna K

Simha \& Dr. Umme Kulsum / Page 337-348

Scaling techniques- The items are constructed as a Likert summated rating scale as suggested by Edward. The scale is a four point scale representing the range of agreement to disagreement.

\section{B. Scoring Key}

The items are scored based on the range of agreement /disagreement that the student chooses. The four points of the scale are Strongly agree, Agree, Disagree and Strongly Disagree. For the items that are scored positively the points awarded range from 4 to 1 from strongly agree to strongly disagree respectively. For items that are scored negatively the order ranges from 1 to 4 from strongly agree to strongly disagree. The scores of all the items as are added to provide a final score. A high total score represents high attitude towards reflective teaching practices whereas a low score represents poor attitude towards reflective teaching practices.

\section{Expert Review}

After the item construction the tool was reviewed by four expert teacher educators with suggestions to improve certain questions, change the structure of certain items, correct grammar etc. After the expert review 32 items were finally selected for try out.

\section{Validity}

Content validity- The content validity was established by the judgement given by the experts. The scale has face validity as the items are closely related to the area it represents as per expert review.

\section{Selection Of Items}

The top-down process of item selection was applied to select the items for the tool. The procedure of item analysis as described by Edward (1969, pp. 152-153) was followed. The tool after expert review was administered to 150 B.Ed., students for the try out. The item analysis was conducted to establish the $t$ value for each statement. The top $27 \%$ of the high scores and the lower $27 \%$ of the low scores were selected as the criterion groups. $t$ test was performed for each statements to 
find the mean difference between the high and the low criterion groups. Edward (1969) suggests that statements with $t$ values greater that 1.968 are to be retained while those scoring lesser than 1.968 are to be rejected. After the item analysis a total of 28 items were retained.

The following Table No.1 shows the results of the item analysis.

Table No. 1: Table showing the $\mathrm{t}$ value of the statements

\begin{tabular}{|l|r|r|}
\hline Sl.No & $\begin{array}{l}\text { New } \\
\text { Item No }\end{array}$ & t-Value \\
\hline 1 & 1 & 3.343 \\
\hline 2 & 2 & 3.06 \\
\hline 3 & Rejected & 1.738 \\
\hline 4 & Rejected & 1.269 \\
\hline 5 & Rejected & 1.883 \\
\hline 6 & 3 & 7.67 \\
\hline 7 & Rejected & 0.71 \\
\hline 8 & 4 & 4.155 \\
\hline 9 & 5 & 8.077 \\
\hline 10 & $* 6$ & 3.495 \\
\hline 11 & 7 & 5.191 \\
\hline 12 & 8 & 2.964 \\
\hline 13 & 9 & 6.797 \\
\hline 14 & $* 10$ & 2.766 \\
\hline 15 & 11 & 6.142 \\
\hline 16 & 12 & 5.455 \\
\hline 17 & $* 13$ & 2.914 \\
\hline 18 & $* 14$ & 4.148 \\
\hline 19 & 15 & 6.203 \\
\hline 20 & $* 16$ & 4.891 \\
\hline 21 & 17 & 5.326 \\
\hline 22 & $* 18$ & 5.541 \\
\hline 23 & 19 & 3.648 \\
\hline 24 & 20 & 4.119 \\
\hline 25 & $* 21$ & 5.033 \\
\hline 26 & 22 & 4.998 \\
\hline 27 & 23 & 3.342 \\
\hline 28 & $* 24$ & 3.059 \\
\hline 29 & 25 & 3.822 \\
\hline & & \\
\hline 19 & & \\
\hline 19 & &
\end{tabular}




\begin{tabular}{|l|r|r|}
\hline 30 & 26 & 9.343 \\
\hline 31 & 27 & 4.19 \\
\hline 32 & 28 & 3.174 \\
\hline
\end{tabular}

II. Internal consistency-

The internal consistency refers to the relatedness of the items with each other. It is the extent to which an item measures the construct. Internal consistency is measured before the final administration to establish the validity if the tool.

a. Cronbach's Alpha- The minimum acceptable value for Cronbach's alpha is 0.70 ; below this value the internal consistency is considered low. Meanwhile, the maximum expected value is 0.90; Above this value is considered as redundancy or duplication. The usual preferred values of Alpha is between 0.80 and 0.90. The Cronbach's Alpha value was calculated for the tool. The obtained Cronbach's Alpha value is 0.892 for 28 items which establishes that the tool has good internal consistency. Table no.2 represents the Cronbach's Alpha value of the tool.

Table No.2: Cronbach's Alpha Value

\begin{tabular}{|c|c|c|}
\hline $\begin{array}{c}\text { Cronbach' } \\
\text { s Alpha }\end{array}$ & $\begin{array}{c}\text { Cronbach's } \\
\text { Alpha Based } \\
\text { on } \\
\text { Standardized } \\
\text { Items }\end{array}$ & $\begin{array}{l}\mathrm{N} \text { of } \\
\text { Items }\end{array}$ \\
\hline .892 & .899 & 28 \\
\hline
\end{tabular}

b. The item total correlations- Item-total statistics were performed to determine the discrimination power of the items. According to Cristobal et al. (2007), the subscales with corrected item-total correlation lower than 0.30 are not acceptable unless the investigator finds the item extremely necessary. Table. No. 3 represents the item total correlations of the scale items. 
Table No. 3: Item-Total Statistics

\begin{tabular}{|l|r|r|r|r|}
\hline & $\begin{array}{c}\text { Scale Mean } \\
\text { if Item } \\
\text { Deleted }\end{array}$ & $\begin{array}{c}\text { Scale } \\
\text { Variance if } \\
\text { Item Deleted }\end{array}$ & $\begin{array}{c}\text { Corrected } \\
\text { Item-Total } \\
\text { Correlation }\end{array}$ & $\begin{array}{c}\text { Cronbach's } \\
\text { Alpha if } \\
\text { Item Deleted }\end{array}$ \\
\hline Cl Ep 1 & 84.08 & 109.914 & .424 & .889 \\
Cl Ep 2 & 84.43 & 107.876 & .398 & .890 \\
Cl Ep 3 & 84.08 & 107.914 & .632 & .886 \\
Cl Ep 4 & 84.50 & 109.400 & .450 & .889 \\
Cl Ep 5 & 84.05 & 107.757 & .619 & .886 \\
Cl Ep 6 & 84.76 & 108.663 & .348 & .891 \\
Cl Ep 7 & 84.18 & 108.312 & .488 & .888 \\
Cl Ep 8 & 84.63 & 109.969 & .286 & .893 \\
IRC 9 & 84.45 & 106.011 & .601 & .885 \\
IRC 10 & 84.96 & 108.412 & .370 & .891 \\
IRC 11 & 84.16 & 109.068 & .540 & .887 \\
IRC 12 & 84.13 & 109.556 & .455 & .889 \\
IRC 13 & 84.97 & 108.773 & .348 & .891 \\
TS 14 & 84.46 & 106.305 & .544 & .887 \\
TS 15 & 84.37 & 109.116 & .540 & .888 \\
TS 16 & 84.67 & 106.837 & .465 & .888 \\
TS 17 & 84.18 & 107.032 & .547 & .887 \\
TS 18 & 84.51 & 105.133 & .485 & .888 \\
AOL 19 & 84.62 & 108.986 & .403 & .890 \\
AOL 20 & 84.36 & 108.232 & .460 & .888 \\
AOL 21 & 84.79 & 106.248 & .461 & .889 \\
AOL 22 & 84.39 & 105.469 & .537 & .887 \\
AOL 23 & 84.20 & 111.067 & .358 & .890 \\
SE 24 & 84.83 & 108.704 & .351 & .891 \\
SE 25 & 84.29 & 110.742 & .320 & .891 \\
SE 26 & 84.22 & 104.923 & .744 & .883 \\
SE 27 & 84.53 & 108.439 & .433 & .889 \\
SE 28 & 84.46 & 108.705 & .365 & .891 \\
\hline
\end{tabular}

III. Construct Validity-

The item-dimension total correlation was computed to establish the construct validity. The Table No.4 gives the values of correlation of each item with it's dimension total. The obtained scores were all significant at 0.01 level. The calculation reveals that there is significant relationship between the items and the dimensions. The correlation coefficients of each dimension total and 
Towards Excellence: An Indexed, Refereed \& Peer Reviewed Journal of Higher Education / Karuna K Simha \& Dr. Umme Kulsum / Page 337-348

the total score of the attitude towards reflective teaching practice scale were computed to observe the relationship between the dimensions and the total scores. The values obtained were significant at 0.01 level, hence showing high correlation between the dimensions and the total. This establishes that the tool has construct validity.

Table No.4: Item-Dimension Total Correlation Values.

\begin{tabular}{|c|c|c|c|c|c|c|c|}
\hline Sl.No & Item & r-value & $\begin{array}{c}\text { Significance } \\
\text { Level } \\
\end{array}$ & SI.No & Item & r-value & $\begin{array}{c}\text { Significance } \\
\text { Level } \\
\end{array}$ \\
\hline 1 & $\mathrm{Cl}$ Ep 1 & $.616^{* *}$ & 0.01 & 16 & TS 16 & $.758^{* *}$ & 0.01 \\
\hline 2 & $\mathrm{Cl}$ Ep 2 & $.573 * *$ & 0.01 & 17 & TS 17 & $.554^{* *}$ & 0.01 \\
\hline 3 & $\mathrm{Cl}$ Ep 3 & $.705^{* *}$ & 0.01 & 18 & TS 18 & $.698^{* *}$ & 0.01 \\
\hline 4 & $\mathrm{Cl}$ Ep 4 & $.597^{* *}$ & 0.01 & 19 & AOL 19 & $.640^{* *}$ & 0.01 \\
\hline 5 & $\mathrm{Cl}$ Ep 5 & $.674 * *$ & 0.01 & 20 & AOL 20 & $.683^{* *}$ & 0.01 \\
\hline 6 & $\mathrm{Cl}$ Ep 6 & $.489 * *$ & 0.01 & 21 & AOL 21 & $.534^{* *}$ & 0.01 \\
\hline 7 & $\mathrm{Cl}$ Ep 7 & $.527^{* *}$ & 0.01 & 22 & AOL 22 & $.721^{* *}$ & 0.01 \\
\hline 8 & $\mathrm{Cl}$ Ep 8 & $.527 * *$ & 0.01 & 23 & AOL 23 & $.511^{* *}$ & 0.01 \\
\hline 9 & IRC 9 & $.672^{* *}$ & 0.01 & 24 & SE 24 & $.555^{* *}$ & 0.01 \\
\hline 10 & IRC 10 & $.568^{* *}$ & 0.01 & 25 & SE 25 & $.463^{* *}$ & 0.01 \\
\hline 11 & IRC 11 & $.673^{* *}$ & 0.01 & 26 & SE 26 & $.714^{* *}$ & 0.01 \\
\hline 12 & IRC 12 & $.617^{* *}$ & 0.01 & 27 & SE 27 & $.702^{* *}$ & 0.01 \\
\hline 13 & IRC 13 & $.622^{* *}$ & 0.01 & 28 & SE 28 & $.660^{* *}$ & 0.01 \\
\hline 14 & TS 14 & $.716^{* *}$ & 0.01 & & & & \\
\hline 15 & TS 15 & $.569^{* *}$ & 0.01 & & & & \\
\hline
\end{tabular}

$(\mathrm{N}=76$, table value at 0.01 level $=0.282)$

Table No.5: Dimension-Total Correlation

\begin{tabular}{|l|l|c|c|}
\hline Sl.No & \multicolumn{1}{|c|}{ Dimension } & r-value & Significance Level \\
\hline 1 & Teaching Strategies (TS) & .846 & 0.01 level \\
\hline 2 & Classroom Episodes (CLEP) & .854 & 0.01 level \\
\hline 3 & $\begin{array}{l}\text { Interpersonal Relationships and } \\
\text { Communication (IRC) }\end{array}$ & .810 & 0.01 level \\
\hline 4 & Assessment Of Learning (AOL) & .817 & 0.01 level \\
\hline 5 & Self-evaluation (SE) & .794 & 0.01 level \\
\hline
\end{tabular}

$(\mathrm{N}=76$, table value at 0.01 level $=0.282)$ 
The items in the scale were finalized after establishing the validity of the tool. The Table No.6 shows the final items selected and the weightages of the components.

\section{E. Reliability}

The reliability was established by computing the correlations between test-retest reliability. The obtained correlation coefficient value is 0.705 (at $\mathrm{N}=57$ ), which is significant at 0.01 level. This shows that the scale has high reliability.

Table No.6 shows the final scale components, items and their respective weightages.

Table No.6 The components and weightages of the Attitude Towards Reflective Teaching Practice (ATRTP) Scale-

\begin{tabular}{|l|l|l|l|l|}
\hline SI.No & Component & Item No & $\begin{array}{l}\text { Total } \\
\text { Items }\end{array}$ & $\begin{array}{l}\text { Weightage } \\
\text { in \% }\end{array}$ \\
\hline 1 & $\begin{array}{l}\text { Teaching strategies } \\
\text { (TS) }\end{array}$ & $14,15,16,17,18$ & 5 & 17.85 \\
\hline 2 & $\begin{array}{l}\text { Classroom Episodes } \\
\text { (CLEP) }\end{array}$ & $1,2,3,4,5,6,7,8$ & 8 & 28.57 \\
\hline 3 & $\begin{array}{l}\text { Interpersonal } \\
\text { Relationship \& } \\
\text { Communication } \\
\text { (IRC) }\end{array}$ & $9,10,11,12,13$ & 5 & 17.85 \\
\hline 4 & $\begin{array}{l}\text { Assessment Of } \\
\text { Learning (AOL) }\end{array}$ & $19,20,21,22,23$ & 5 & 17.85 \\
\hline 5 & Self-Evaluation (SE) & $24,25,26,27,28$ & 5 & 17.85 \\
\hline & Total & & 28 & $99.97 \%$ \\
\hline
\end{tabular}

\section{F. Reliability}

The reliability was established by computing the correlations between test-retest reliability.the obtained correlation coefficient value is 0.705 (at $\mathrm{N}=57$ ), which is significant at 0.01 level. This shows that the scale has high reliability.

\section{Conclusion}

Though reflections are taken from time to time by teachers during their routine classroom teaching, consciously practicing reflective teaching is treated novel by the teachers. As per the recommendations of NCTE, NCF-2005 and New Education Policy 2020, there has been a 
paradigm shift in the approaches of teaching from teacher centered to student centered. This may cause stress to the teachers to adapt to the new idea of reflective practices. Hence inculcating a positive attitude towards reflective teaching enables the process of adapting to the new idea with ease. Proper support and training to the teachers, in the same way helps improve attitudes and hence accelerates the process of accommodating new changes. Therefore measurement of the attitude towards reflective teaching practices enable the teacher educators, educationists and educational administrators to understand the attitudes and hence make way to overcome the difficulties, thereby developing better attitudes of the teachers making them reflective practitioners. 


\title{
References
}

1. Carmines, E., \& Zeller, R. (1979). Reliability and validity assessment. https://doi.org/10.4135/9781412985642

2. Designing the reflective teaching model. (2017). Reflection in Action, 71-82. https://doi.org/10.4324/9781315245065-10

3. Edwards, A. L. (1983). Techniques of attitude scale construction. Ardent Media.

4. Pollard, A., \& Collins, J. (2005). Reflective teaching. A\&C Black.

5. (n.d.). https://ncte.gov.in/website/PDF/NCFTE_2009.pdf

6. New Education Policy. (2020). Ministry of human resource, Government of India. https://www.education.gov.in/sites/upload_files/mhrd/files/NEP_Final_English_0. pdf

\author{
Karuna K Simha \\ Research Scholar, \\ Department of Education, Bangalore University, Bangalore \\ Email Id- karunasimha@gmail.com, (M): 09591075908 \\ \& \\ Dr. Umme Kulsum \\ Professor, \\ Department of Education, Bangalore University, Bangalore \\ Email Id: ummekulsum14@yahoo.co.in
}

